\title{
A relação entre imputabilidade e liberdade em Kant
}

\section{Lucas H. de Almeida*, Monique Hulshof}

\section{Resumo}

Com esta pesquisa, busquei estudar o modelo de imputabilidade oferecido por Kant em sua "Metafísica dos Costumes", a propósito de analisá-lo sob a luz dos resultados obtidos pelo idealismo transcendental respeitante à ideia de liberdade, especialmente pelos efeitos desta última perante as pretensões da razão previamente enunciadas pela Primeira Crítica.

\section{Palavras-chave: \\ Kant, imputabilidade, liberdade.}

\section{Introdução}

1. Na Metafísica dos Costumes, Kant define "imputação", em sentido moral, como sendo um juízo mediante o qual certa pessoa é considerada como a autora (causa libera) por trás de uma determinada ação que, como ele conclui, embolsa o título de "feito" (factum) e encontra-se sob leis.

2. Imputar uma ação a alguém significa, por conseguinte, estabelecer uma relação entre o acontecimento (factum), e a pessoa que é considerada como a autora deste feito, ou melhor, como a causa livre por trás de sua ocorrência.

3. Uma vez que tal relação foi estabelecida com sucesso, extraímos as possíveis consequências do feito analisado. Estas últimas podem ser de duas espécies em particular, sendo estas tanto consequências jurídicas como morais.

4. A natureza da consequência aplicável a certo factum é, por sua vez, determinada pela lei sob a qual ele se situa. Deste modo, a violação de uma lei jurídica será seguida, então, por suas consequências prescritas juridicamente; uma ofensa à lei moral fará despontar, em contrapartida, as consequências morais e internas de sua transgressão.

5. Segundo Kant, os requisitos para a imputabilidade são, portanto, a possibilidade de considerarmos uma pessoa como a causa livre por trás de um dado feito, de um lado; seguido da possibilidade de o compararmos com uma lei, sendo ela jurídica ou, ainda, puramente moral, pelo outro.

6. Dito isso, o intento desta minha pesquisa consistia em, primeiramente, analisar o primeiro requisito mencionado, o qual podemos tomar como "o requisito da causa libera". Nesta etapa, busquei estudar seus fundamentos teóricos, bem como a sua função dentro do pensamento kantiano, a fim de compreender em que medida uma pessoa pode, em Kant, ser considerada como a autora de certo factum.

\section{Resultados e Discussão}

1. Pesquisar os fundamentos teóricos de uma causa livre tornou-se uma tarefa de regressão, como era imaginado. $E$ foi assim que, da definição enunciada por Kant na $M C$, voltei-me à Terceira Antinomia da Crítica da Razão Pura.

2. Nela, a possibilidade de uma causa libera é concebida, antes de mais nada, segundo uma maneira problemática: como uma ideia necessariamente estruturada pela razão, a fim de solucionar as suas pretensões de conhecimento.
3. Visando atingir uma pretensa completude sistemática, a razão formula a possibilidade de uma causalidade livre, ou melhor, uma causalidade sem precedentes temporais, como sendo, ela própria, certa "causalidade espontânea", descrita por sua capacidade para dar origem a si mesma.

4. Essa capacidade se intitula "liberdade transcendental", e dela se fundamentaria o conceito prático de liberdade, pelo qual Kant tencionava caracterizar o arbítrio humano: um arbítrio dotado de uma peculiar capacidade para agir independentemente dos impulsos de nossa sensibilidade.

5. Porém, enquanto é marcada por essa espontaneidade, a possibilidade de uma causalidade livre parecia colocar, em princípio, um segundo tipo de causalidade sob risco, o qual Kant denominava como "causalidade da natureza", segundo a qual toda causa encerraria, necessariamente, uma causalidade anterior e identificável dentro do tempo.

6. Com vistas a conciliar ambos os tipos de causalidade, Kant utiliza de seu idealismo transcendental para, assim, estabelecer o discernimento de dois campos de atuação: (a) o campo fenomênico, dentro do qual a causa naturae continua detentora daquele seu estatuto de necessidade, e cujo conhecimento nos seria uma possibilidade factual; (b) o campo numênico, no interior do qual a causa libera, ainda que não desponte como passível de conhecimento, tornaria a se revelar como possibilidade em pensamento.

\section{Conclusões}

1. Assim, conforme o modelo kantiano de imputabilidade, a autoria por trás de um feito se encontraria condicionada a uma ideia de causalidade livre que está fundamentada, puramente, enquanto uma possibilidade em pensamento; então, ela não compartilharia da mesma cognoscibilidade pela qual a causalidade da natureza pôde se caracterizar.

2. Parece ser este o motivo pelo qual Kant concluíra que: "a efetiva moralidade das ações (mérito e culpa), mesmo em nosso próprio comportamento, permanece, portanto, inteiramente oculta para nós. [...] O quanto delas, porém, pode ser imputado ao puro efeito da liberdade, o quanto à mera natureza ou ao erro inocente do temperamento, [...] isto é algo que ninguém pode estabelecer com rigor, e nem, portanto, julgar com inteira justiça." [ $K r V$, B 579]. Contudo, uma vez que a liberdade é concebida, em Kant, como uma ideia sem a qual não poderíamos sequer agir, a imputabilidade humana termina por compartilhar deste mesmo estatuto de "ideia necessária" tido pela liberdade. 